
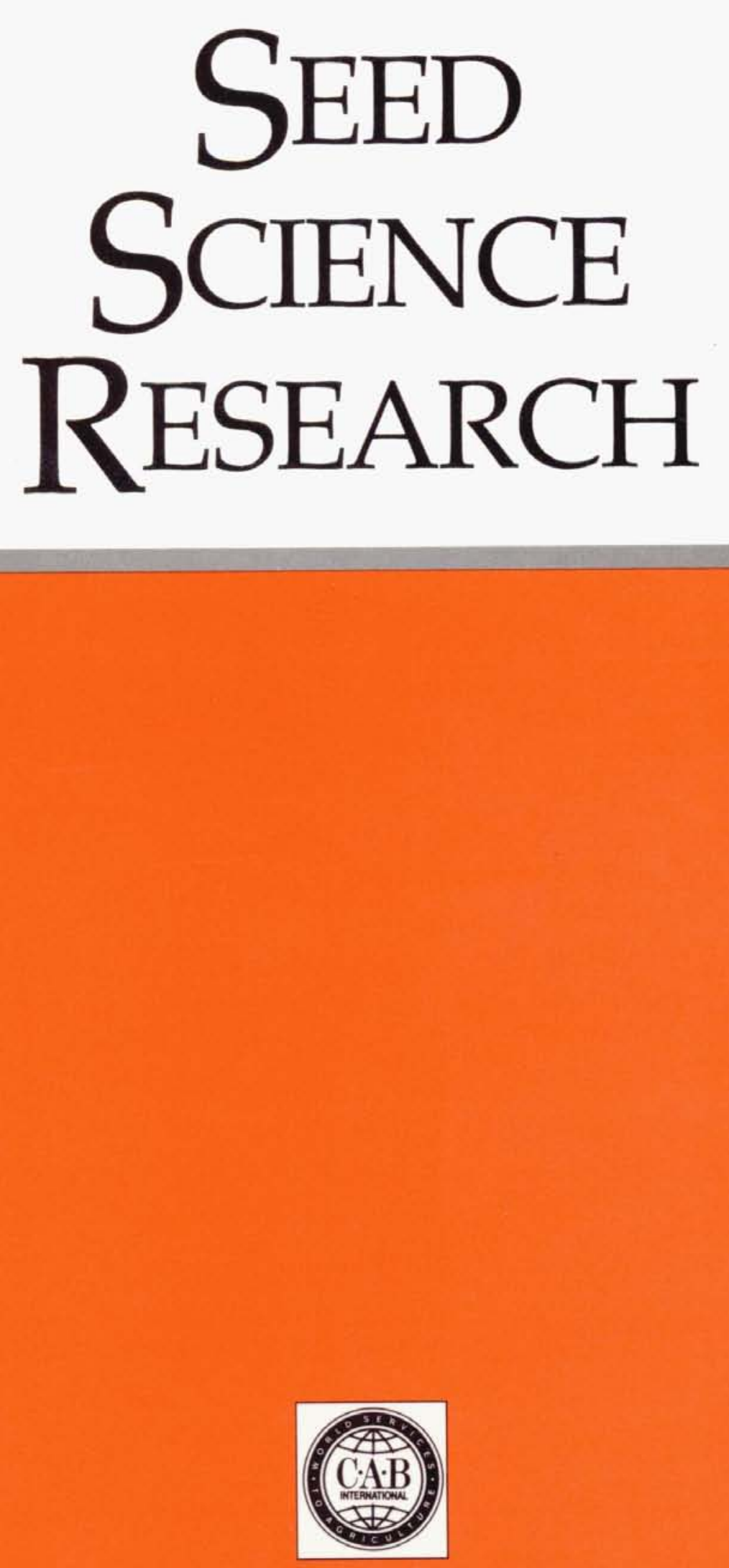

$C \cdot A \cdot B$ International 


\section{SEED SCIENCE RESEARCH}

Seed Science Research is an international journal specifically addressing basic scientific research on seeds published quarterly by $C \cdot A \cdot B$ International

Editor:

\section{Associate Editors:}

Review Board:

J. D. Bewley, Guelph, Canada

J. W. Bradbeer, London, UK

C. M. Bray, Manchester, UK

D. Côme, Paris, France

A. Crozier, Glasgow, UK

A. Cuming, Leeds, UK

M. Delseny, Perpignan, France

G. Egley, Stoneville, USA

R. H. Ellis, Reading, UK

M. Fenner, Southampton, UK

G. B. Fincher, Bundoora, Australia

B. Frankland, London, UK

J. Greenwood, Guelph, Canada

P. J. Grime, Sheffield, UK

M. A. Hall, Aberystwyth, UK

Seed Science Research is a medium for original articles on the physiology, biochemistry and molecular biology of seeds, covering seed and embryo development, maturation, dormancy, germination, viability, longevity, vigour, reserve mobilization, and the early stages of establishment. Papers on ecology, ecophysiology and applied research (e.g.
M. Black, London, UK

R. D. Hill, Winnipeg, Canada

C. M. Karssen, Wageningen, Netherlands

C. F. Jenner, Glen Osmond, Australia

A. C. Leopold, Ithaca, USA

A. Marcus, Philadelphia, USA

A. Mayer, Jerusalem, Israel

B. McKersie, Guelph, Canada

R. Obendorf, Ithaca, USA

D. Osborne, Oxford, UK

N. Pinfield, Bristol, UK

A. Pradet, Bordeaux, France

E. H. Roberts, Reading, UK

P. Schopfer, Freiburg, Germany

E. Vigil, Beltsville, USA

M. K. Walker-Simmons, Pullman, USA

T. L. Wang, Norwich, UK

priming, pelleting, biotechnology) will also be included if they have a sound theoretical base or a high physio-biochemical content and/or relevance. The journal includes review articles, both commissioned and contributed, and letters (see Notes for Authors)

Authors should submit original manuscript and artwork plus two copies to:

Professor M. Black, Division of Life Sciences,

King's College London, Campden Hill Road, London, W8 7AH, UK

(see Notes for Authors)

Orders and enquiries concerning subscriptions should be sent to:

Marketing and Distribution Services,

C.A.B INTERNATIONAL,

Wallingford, Oxon, OX10 8DE, UK.

Telephone: Wallingford (0491) 832111

Telex: 847964 (COMAGG G)

Fax: (0491) 833508

Telecom Gold/International Dialcom: 84: CAU001

\section{Disclaimer}

The information contained herein, including any expression of opinion and any projection or forecast, has been obtained from or is based upon sources believed by us to be reliable but is not guaranteed as to accuracy or completeness. The information is supplied without obligation and on the understanding that any person who acts upon it or otherwise changes his/her position in reliance thereon does so entirely at his/her own risk.

$C \cdot A \cdot B$ International does not accept responsibility for any trade advertisement included in this publication. 


\section{Seed Science Research}

Review Article

Farrant, J. M., Pammenter, N. W., \& Berjak, P. Seed development in relation to desiccation tolerance: A comparison between desiccation-sensitive (recalcitrant) seeds of Avicennia marina and desiccation-tolerant types

Research Papers

Ashraf, M., \& Bray, C. M. DNA synthesis in osmoprimed leek (Allium porrum L.) seeds and evidence for repair and replication

Berry, T., \& Bewley, J. D. Comparisons between the roles of the fruit tissues, osmoticum and abscisic acid in maintaining tomato seed development and storage protein synthesis

Chiatante, D., \& Onelli, E. Nuclear proteins and the onset of cell proliferation in root meristems of Pisum sativum: QP47 a novel acidic protein.

Elder, R. H., \& Osborne, D. J. Function of DNA synthesis and DNA repair in the survival of embryos during early germination and in dormancy....

Farrant, J. M., Berjak, P., Cutting, J. G. M., \& Pammenter, N. W. The role of plant growth regulators in the development and germination of the desiccation-sensitive (recalcitrant) seeds of Avicennia marina

Lai, D. M. L., Slade, A. M., \& Fincher, G. B. Development and regulation of $(1+3,1 \rightarrow 4)$ - $\beta$-glucan endohydrolases in germinating wheat (Triticum aestivum)

Book Reviews

Abstracted in Seed Abstracts (CAB ABSTRACTS),

Current Advances in Plant Science and BIOSIS

(c) C.A.B International, 1993

All rights reserved. No part of this publication may be reproduced, in any form or by any means, electronically, mechanically, by photocopying, recording or otherwise. without prior permission of the copyright owner. 